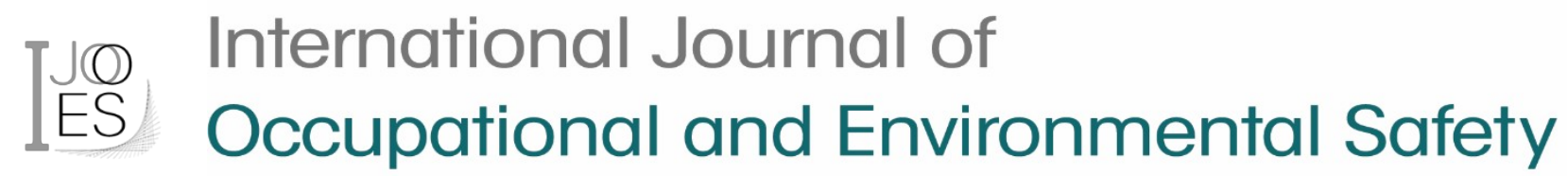

\section{The use of surface electromyography in assessing the effectiveness of manual therapy: a systematic review}

\author{
Rui J osé Santiago ${ }^{a}$, J. Santos Baptistab ${ }^{b}$ André Magalhães ${ }^{c}$, J. Torres Costa ${ }^{d}$ \\ aLaboratory on Prevention of Occupational and Environmental Risks, Faculty of Engineering, University of Porto, Porto, \\ PT (rui.santiago@gmail.com). bैAssociated Laboratory for Energy, Transports and Aeronautics, Faculty of Engineering, \\ University of Porto, Porto, PT (jsbap@fe.up.pt) ORCID: 0000-0002-8524-5503. ' School of Health Sciences, University \\ Fernando Pessoa, Porto, PT (andrem@ufp.edu.pt). ${ }^{d}$ Laboratory on Prevention of Occupational and Environmental \\ Risks, Faculty of Medicine, University of Porto, Porto, PT (zecatoco@sapo.pt).
}

\section{Article History}

Received 10 September 2020

Accepted 6 J anuary 2020

Published 20 April 2020

\section{Keywords}

sEMG

Electromyography

Manual therapy effectiveness

Categorization

DOI :

10.24840/2184-0954_004.001_0008

I SSN:

2184-0954

Type:

Review

ठิ Open Access

Peer Reviewed

(c) $\mathrm{CC}$ BY

\begin{abstract}
Research on the use of surface electromyography (sEMG) for analyzing the effects of Manual Therapy (MT) seems to have very dispersed intentions. The development of data collection protocols using sEMG might not be stable for conducting clinical studies. This study aimed to evaluate the current literature using surface SEMG in the context of MT and verify if it is a useful tool to verify its effectiveness. Also, to assess the methodologic quality and reporting standards and make a reflective analysis of how this technique has been used for this treatment modality. A computerized search was performed in May 2017 and repeated in June 2018, the search was performed in 8 electronic databases following PRISMA protocol. Thirty-one papers were included. More and betterdesigned studies are needed to create improved protocols. Further exploration and validation of these protocols may help to conduct more reliable clinically driven trials and it may inform policymakers of the role of MT in health care. The detection of clinically meaningful electrical alterations in muscles seems to be the main objective of most authors. Several SEMG items were not reported, and overall methodology quality was low.
\end{abstract}

\section{I NTRODUCTION}

Manual therapy (MT) has had a relevant role in health care since the very early ages (Paris, 2000). The use of manual skills to address health issues was documented by Hippocrates (460355 BC) on his book 'On setting bones by leverage,' where he describes the application of a vertebral manipulation (Withington, 1944). Osteopathic Medicine and Chiropractic, created in the United States in 1874 and 1895, respectively, and Physiotherapy in the United Kingdom in 1899, are among the first professionalization of the use of Manual therapy (Smith, 2007).

MT modalities as physical treatment and spinal manipulation are likely to be cost-effective options (Andronis et al., 2017; Licciardoni, 2014). Evidence suggests that types of manual therapy as mobilization, manipulation, and clinical massage are effective interventions for the management of neck pain and reductions in intensity and frequency of chronic cervicogenic dizziness (Wong et al., 2016; Reid al., 2014).

Primary health care providers should be mindful of the use of this highly accepted, low serious risk, approach to musculoskeletal conditions when deciding the best course of action (ArmijoOlivo et al., 2016; Fernandez-de-Las-Penas et al., 2017; Swait and Finch, 2017; Moore et al., 
2017; Chou, 2009). Different techniques have been used to assess the effectiveness/efficacy of MT, among them there is surface electromyography (sEMG).

sEMG is a non-invasive technique to measure de degree of myoelectric activity (Ko et al., 2015; Herzog et al., 1999), in use since the 1960s for clinical research (Al-Mulla et al., 2011). sEMG can measure motor unit properties (as muscle fibre conduction velocity or location of innervation zones), difficult to assess using the common invasive indwelling electromyography. Its use can detect more motor units concerning selective intramuscular recordings (Merletti and Farina, 2016). Also, when compared with other technologies, sEMG stands out as the most efficient in identifying and predicting muscle fatigue (Al-Mulla et al., 2011) and its high-density version can analyze motor units (Merletti et al., 2008). According to Barbero et al., (2012), sEMG can be helpful to evaluate if treatments and training are effective and assess the risk of developing occupational disorders, being able to monitor and record changes in the neuromuscular system.

For spinal manipulation (SM), mainly, SEMG has been used to document change but, more work needs to be done to understand the mechanisms and significance of these changes (Lehman, 2012). sEMG may have a role as a prognostic tool for chronic LBP rehabilitation (Hu et al., 2014), due to the significant difference between healthy and LBP groups in the quantitative time-varying analysis of the sEMG topography. The reporting standards for the use of SEMG were defined by the International Society of Electrophysiology and Kinesiology

To date and authors knowledge, no systematic review has been conducted on categorizing the purposes of the use of sEMG in MT interventions and verify if sEMG may be used to assess the effects of MT.

This review also aims to analyze all articles that used SEMG for MT to assess the methodological quality of the studies and the inclusiveness of the reporting of SEMG.

\section{METHODOLOGY}

This study adheres to the PRISMA guidelines for reporting systematic reviews and metaanalysis (Liberati et al., 2009). A systematic review protocol (Santiago et al., 2018) has been prepared using the preferred reporting items for systematic reviews and meta-analysis protocols - PRISMA-P (Moher et al., 2015) and registered on Prospero database (Ref: CRD42018087499).

\subsection{Search Strategy}

The following electronic databases were searched: SCOPUS, ScienceDirect, WebOfScience, PUBMED, Physiotherapy Evidence Database (PEDro), Biomed CENTRAL, Directory of Open Access J ournals (DOAJ) and MEDLINE. The reference list of papers was screened for earlier and relevant studies were added to the included list of articles.

The terms used in the search strategy were:

"( ((high AND density AND surface AND electromyography) OR (multichannel AND surface AND electromyography) OR (surface AND electromyography)) AND ((manual AND therap*) OR (manual AND treatment) OR physiotherap* OR osteopath* OR chiro* OR (occupational AND therap*) OR orthop* OR massag*)) AND NOT (systematic AND review))". This query was adapted to the different database search engine specifications; all adaptations are listed in Appendix 1.

\subsection{Selection of Studies and Data Extraction}

The inclusion criteria for this review are: (1) The study protocol must include the application of MT; (2) Must present objective measures with surface electromyography of the use of MT; (3) Articles from 2014 was considered adequate as older, relevant articles would be referenced in the newer studies and were, therefore, included after a reference and authors search; (4) Participants are adult humans; (5) Articles in English only.

Two reviewers (RJS and JSB) independently searched the databases and journals and screened the titles and abstracts for eligibility and extracted data using a standard data extraction form. This form was developed in a spreadsheet, by database, to organize the inclusion of articles. 
Full texts of the studies that meet the inclusion criteria were screened by the same two reviewers. The disagreements occurred between authors during studies selection were solved by another author (JTC).

\subsection{Data Analysis and Synthesis}

The retrieved data was divided structured and analyzed in two parts. First, the generic study's information regarding participants and interventions and a second on the specific data regarding SEMG usage.

The descriptive data variables are: number of participants; mean age; sex; body-mass index (BMI) $(\mathrm{kg} / \mathrm{m} 2)$; country; recruitment method; inclusion/exclusion criteria; assessment by health professional; methodology; control group; other measuring methods; MT techniques used; duration of MT intervention; who applied the MT and area of the body treated.

The sEMG variables extracted were: surface electrodes (material, shape, size, skin preparation, int. electrode distance, location); EMG detection (type of differential, input impedance, common-mode rejection ratio (CMRR), signal to noise ratio (SNR), gain, Filter types, cut-off frequencies, slopes of the cut-off); Sampling (frequency, bits); Normalization (training of contraction, joint angle, conditions [angle of adjoining joint], rate of rise, velocity, ranges, load); and rectification and amplitude process.

No meta-analysis was planned, and a descriptive analysis of the data is presented. The retrieved information is summarized in a narrative synthesis and illustrated descriptively.

\subsection{Quality Assessment}

The risk of bias for the included studies was assessed using the Jadad scale (Jadad et al., 1996) for descriptive analysis.

\section{RESULTS}

\subsection{Study Selection}

Figure 1 shows the process of identifying and screening articles and the application of the inclusion criteria to a final selection of 31 studies.

\subsection{Categorization of Purposes}

The purposes of the 31 studies selected have been divided into three different categories:

- Comparing MT treatment protocols: 4 articles.

- Verify the efficacy/effectiveness of the MT intervention in symptoms: 8 articles.

- Test sEMG protocols for MT: 24 articles.

Table 1, Table 2 and Table 3 present the most relevant items for analysis and comparison. Some studies had more than one purpose in their objectives; the results for each category are presented below. 


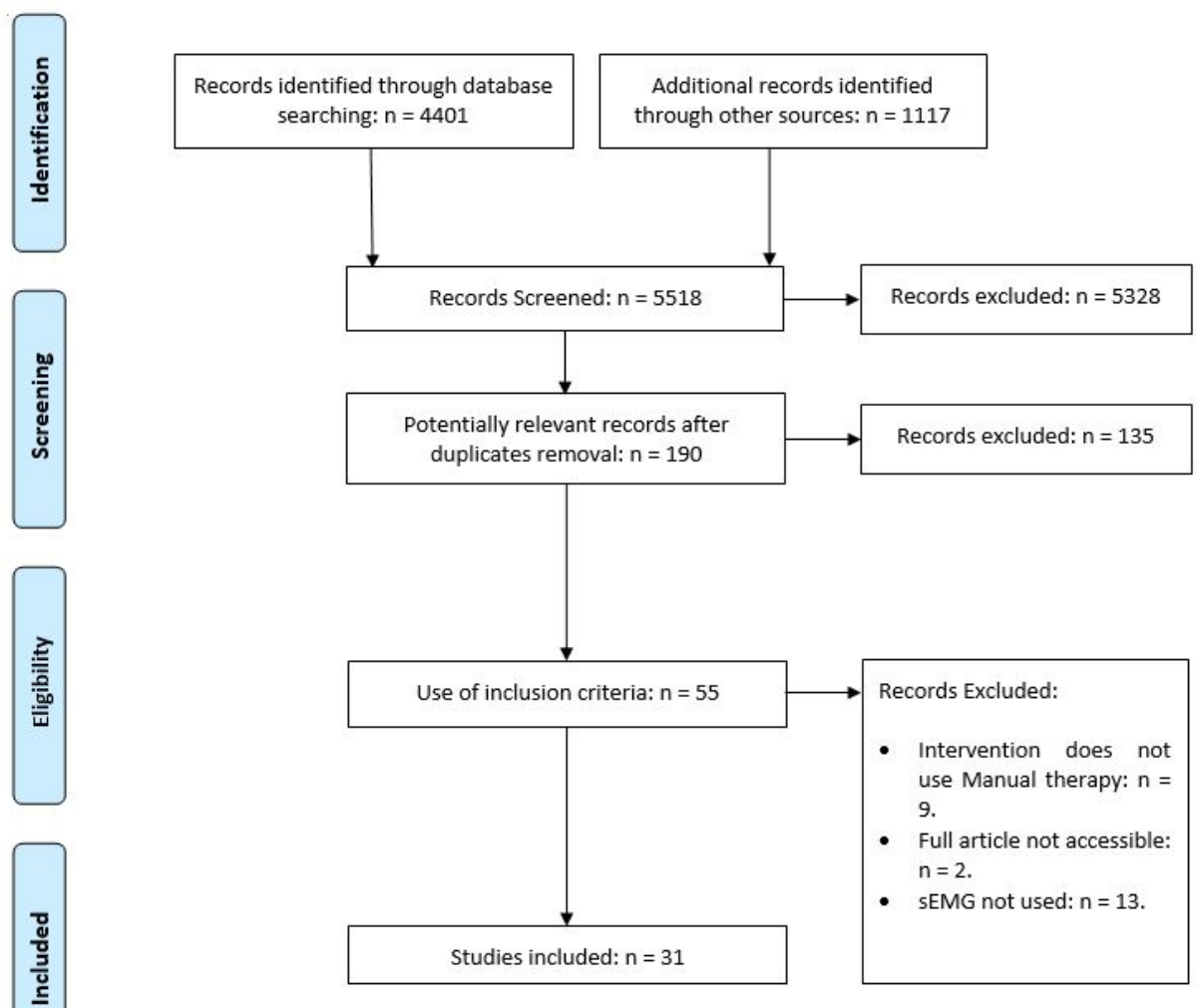

Figure 1. PRISMA statement selection criteria process

\section{Comparing MT treatment Protocols}

Only four studies had the objective of analyzing the sEMG results among different MT treatment approaches. The effectiveness of craniosacral therapy techniques and trigger point therapy was examined and found that both can effectively reduce the intensity and frequency of LBP although craniosacral therapy (CST), unlike trigger-point therapy (TPT), reduces the tension at the multifidus muscles (Bialoszewski et al., 2014). The work of Ritvanen et al. (2007) aimed to compare traditional bone setting (TBS) and physical therapy (PTh), also for LBP, indicating that both reduce the subjective feeling of pain, but TBS showed better results than PTh. No association between symptoms and SEMG parameters was found. GalindezIbarbengoetxea et al. (2017) found that the short-term effect of high-velocity low-amplitude thrust (HVLAT) technique was only marginally better in improving function and reducing pain than home exercises. The last study, by Yoopat et al. (2015), compared three different Thai Massage methods, no significant differences were found, interesting that in all method's adverse effects at the shoulder muscles were reported.

There is still very little comparative evidence to favour any treatment modality for a given clinical context.

\section{Verify the efficacy/effectiveness of the MT intervention in symptoms}

Eight studies felt into this category. Physiotherapy treatment using mobilization accounts as half of them. The works of Kamel et al. (2016) and Pecos-Martina et al. (2017) used posterioranterior (PA) mobilization, the former in lumbar spine and latter the thoracic spine, in both cases a decrease in local pain and muscle activity were observed. Also, in the spine, the study from $\mathrm{Hu}$ et al. (2014) showed significant differences in sEMG topography after mobilization, between the chronic LBP and healthy subjects. Shih et al. (2018) were interested in the potential effects of adding joint mobilization to exercise training on the neuromuscular performance of subjects with functional ankle instability (FAI). It resulted in additional benefits in self-reported ankle instability, mobility, and balance but uncertainty remains regarding general improvement and muscle activation. Xia et al. (2017) observed clinical and statistically significant improvement in pain intensity and disability in chronic LBP participants after the application of 12 sessions of SM but only small changes concerning global stiffness. 
Table 1. Use of sEMG in Manual Therapy: Demographics

\begin{tabular}{|c|c|c|c|c|c|c|}
\hline Author(s) & $\begin{array}{l}\text { Number of } \\
\text { Participants }\end{array}$ & Age Mean & Sex & BMI & Country & Recruitment Method \\
\hline Barbosa et al. (2014) & 20 & 22.67 & N/A & Yes & Brazil & Public call \\
\hline Begovic et al. (2016) & 29 & N/A & $M$ & N/A & China & University \\
\hline Behm et al. (2013) & 17 & $\mathrm{~F}(22.2) \mathrm{M}(31)$ & $\begin{array}{l}13 \mathrm{~F} \\
4 \mathrm{M}\end{array}$ & Yes & Canada & University \\
\hline$\frac{\text { Bialoszewski et al. }}{(2014)}$ & 55 & CST (33), TPT (33) & $\mathrm{N} / \mathrm{A}$ & N/A & Poland & N/A \\
\hline$\frac{\text { Cruz-Montecinos et al. }}{(2016)}$ & 16 & $\begin{array}{c}\text { Experimental (64.37), Control } \\
(61)\end{array}$ & $\mathrm{F}$ & Yes & Chile & Hospital \\
\hline$\frac{\text { Currie et al. (2016) }}{\text { (a) }}$ & 17 & $M(31.6) F(28.8)$ & 8 F 9 M & Yes & USA & N/A \\
\hline$\frac{\text { Currie et al. (2016) }}{\text { (b) }}$ & 40 & 32.6 (NS) 33.4 (S) & $\mathrm{N} / \mathrm{A}$ & Yes & USA & N/A \\
\hline DeVocht et al. (2005) & 16 & N/A & N/A & $\mathrm{N} / \mathrm{A}$ & USA & Clinic \\
\hline Domingo et al. (2017) & 17 & 24.5 & $9 \mathrm{~F} 8 \mathrm{M}$ & $\mathrm{N} / \mathrm{A}$ & USA & N/A \\
\hline$\frac{\frac{\text { Galindez- }}{\text { Ibarbengoetxea et al. }}}{(2018)}$ & 27 & MT (32.15) HE (34.35) & $\mathrm{F}$ & Yes & Spain & Public call \\
\hline$\frac{\text { Gentilcore-Saulnier et }}{\text { al. (2010) }}$ & 22 & PVD (22) Control (21) & $\mathrm{F}$ & Yes & Canada & University \\
\hline Haavik et al. (2018) & 19 & 29.5 & $3 \mathrm{~F} 16 \mathrm{M}$ & $\mathrm{N} / \mathrm{A}$ & New Zealand & N/A \\
\hline$\frac{\text { Hagovska et al. }}{(2014)}$ & 55 & $M(46.77) \mathrm{H}(40.53)$ & $50 \%$ M 50\% F & Yes & Slovakia & Hospital \\
\hline Herzog et al. (1995) & 2 & $22(F) 33(M)$ & $1 \mathrm{~F} 1 \mathrm{M}$ & Yes & Canada & N/A \\
\hline Herzog et al. (1999) & 10 & $21-41$ & M & $\mathrm{N} / \mathrm{A}$ & Canada & Volunteer \\
\hline Hu et al. (2014) & 81 & NS (32) S (42) & $30 \mathrm{~F} 51 \mathrm{M}$ & $\mathrm{N} / \mathrm{A}$ & Hong-Kong & N/A \\
\hline Hunter et al. (2006) & 10 & $21.5(0.5)$ & N/A & $\mathrm{N} / \mathrm{A}$ & UK & N/A \\
\hline Kamel et al. (2016) & 45 & $37.4 ; 38.33 ; 37.46$ & $\mathrm{~F}$ & Yes & Egypt & Hospital \\
\hline Ko et al. (2015) & 63 & $24.0 ; 25.3$ & $42 \mathrm{~F} 17 \mathrm{M}$ & $\mathrm{N} / \mathrm{A}$ & Taiwan & N/A \\
\hline$\frac{\text { Krekoukias et al. }}{(2009)}$ & 36 & 26.8 & $26 \mathrm{~F} 10 \mathrm{M}$ & Yes & Greece & $\mathrm{N} / \mathrm{A}$ \\
\hline$\frac{\text { Langdon R. (2011) }}{\text { Niazi et al. (2015) }}$ & $\begin{array}{l}34 \\
18\end{array}$ & $\begin{array}{c}34,1 \\
(10-26,7)(8-32,6)\end{array}$ & $\begin{array}{c}29 \mathrm{~F}, 5 \mathrm{M} \\
\mathrm{M}\end{array}$ & $\begin{array}{l}\text { N/A } \\
\text { N/A }\end{array}$ & $\begin{array}{c}\text { USA } \\
\text { New Zealand }\end{array}$ & $\begin{array}{l}\text { Public call } \\
\text { Volunteer }\end{array}$ \\
\hline$\frac{\overline{\text { Pecos-Martín et al. }}}{(2017)}$ & 34 & 24 & $\begin{array}{c}E(11 F, 6 M), P \\
(8 F, 9 M)\end{array}$ & Yes & Spain & University \\
\hline Reznik et al. (2015) & 12 & 23.8 & $10 \mathrm{~F} 2 \mathrm{M}$ & Yes & Australia & Hospital \\
\hline$\underline{\text { Ribeiro et al. (2017) }}$ & 22 & 23.5 & $11 \mathrm{~F} 11 \mathrm{M}$ & Yes & New Zealand & Public call \\
\hline Ritvanen et al. (2007) & 61 & $\mathrm{M}(40,8 ; 41) \mathrm{F}(40,6 ; 42)$ & 27 F 34 M & Yes & Finland & Public call \\
\hline Shih et al. (2018) & 45 & $\begin{array}{c}\text { CG (27.9) TG (26.9) MTG } \\
(26.5)\end{array}$ & $\begin{array}{l}\text { CG (8F 7M) TG (8F } \\
7 M) \text { MTG (5F 10M) }\end{array}$ & Yes & Taiwan & N/A \\
\hline$\frac{\text { Shin. and Sung. }}{(2015)}$ & 21 & $20.55 ; 20.90$ & $6 \mathrm{~F} 15 \mathrm{M}$ & Yes & South Korea & Volunteer \\
\hline Suter et al. (2005) & 32 & Group 1 (25) Group 2 (32) & N/A & N/A & Canada & University \\
\hline Xia et al. (2017) & 82 & 44.9 & $39 \mathrm{~F} 43 \mathrm{M}$ & Yes & USA & Public Call \\
\hline Yoopat et al. (2015) & 30 & 37.97 & $\mathrm{~F}$ & Yes & Thailand & Volunteer \\
\hline
\end{tabular}

The Post-operative care role of manual therapy, particularly massage, was the object of study of Ko et al. (2015), although the mastication muscles activity showed benefits after the intervention, overall no significant recovery was found. Significant differences between intervention and control groups were found in Hagovska et al. (2014), regarding erector spinae tension and pain perception but not in disability, based on the centralization phenomenon that occurred after application of McKenzie method for chronic LBP. On the last study for this category, Gentilcore-Saulnier et al. (2010) work aimed at understanding the benefits of manual therapy on the pelvic floor muscles in women with and without provoked vestibulodynia (PVD). There was empirical evidence of decreased pressure sensitivity, vulvar pain, and tolerance to vaginal penetration.

\section{Test sEMG protocols for MT}

This category had the most contribution of all, 24 studies. The use of SM was present in eight of them. Currie at el. (2016b) study had the objective to standardize methods for onset detection (double threshold and cross-correlation) for SM; the findings suggested that the double-threshold was the best option. Currie et al. (2016a) found that chronic LBP participants have less muscle electric activity and a longer onset delay after the application of the technique. Same results by DeVocht et al. (2005) found a generalized reduction in SEMG levels after HVLAT. This result shows the opposite of Herzog et al. (1995) findings in which it is suggested that the reflex response causes muscle activation (for fast treatment thrusts) no relation with the cavitation phenomenon (joint physiological reaction) was found. Suter et al. 
(2005) found that changes in Hoffman reflexes (H-reflex) amplitude was only observed in patients with LBP after the application of sacroiliac (SI) HVLAT. Alterations to the H-reflex to investigate the excitability of the low-threshold neurons that seem to prevent fatigue was the objective of Niazi et al., (2015). The same technique was used to perceive its effect on reflex responses; results were very consistent in all spine for asymptomatic subjects (Herzog et al., 1999).

Table 2. Use of sEMG in Manual Therapy: Methodology

\begin{tabular}{|c|c|c|c|c|c|}
\hline Author(s) & $\begin{array}{l}\text { Inclusion } \\
\text { / Exclusion Criteria }\end{array}$ & $\begin{array}{c}\text { Assessment by } \\
\text { Health } \\
\text { Professional }\end{array}$ & Methodology & Control Group & $\begin{array}{l}\text { Other (than sEMG) } \\
\text { Measuring Methods }\end{array}$ \\
\hline$\frac{\text { Barbosa et al. }}{(2014)}$ & Yes & Yes & Intervention & No & No \\
\hline Begovic et al. (2016) & Yes & $\mathrm{N} / \mathrm{A}$ & RCT & Yes & Yes \\
\hline Behm et al. (2013) & Yes & $\mathrm{N} / \mathrm{A}$ & Experimental: 4 Interventions & Yes & No \\
\hline$\frac{\text { Bialoszewski et al. }}{(2014)}$ & Yes & Yes & Randomized, 2 groups & No & Yes \\
\hline$\frac{\text { Cruz-Montecinos et }}{\text { al. (2016) }}$ & Yes & Yes & RCT & Yes & Yes \\
\hline$\frac{\text { Currie et al. (2016) }}{\text { (a) }}$ & Yes & Yes & Intervention & No & Yes \\
\hline$\frac{\text { Currie et al. (2016) }}{\text { (b) }}$ & Yes & Yes & Intervention & No & Yes \\
\hline$\frac{\text { DeVocht et al. }}{(2005)}$ & Yes & Yes & Descriptive Study & No & No \\
\hline$\frac{\text { Domingo et al. }}{(2017)}$ & $\mathrm{N} / \mathrm{A}$ & $\mathrm{N} / \mathrm{A}$ & Randomized Crossover Study & No & No \\
\hline$\frac{\frac{\text { Galindez- }}{\text { Ibarbengoetxea et }}}{\text { al. }(2018)}$ & Yes & Yes & Randomized Clinical Trial, 2 groups & No & Yes \\
\hline$\frac{\text { Gentilcore-Saulnier }}{\text { et al. } 2010}$ & Yes & Yes & RCT & Yes & No \\
\hline Haavik et al. (2018) & Yes & N/A & $\mathrm{RCT}$ & Yes & Yes \\
\hline$\frac{\text { Hagovska et al. }}{(2014)}$ & Yes & Yes & RCT & Yes & Yes \\
\hline Herzog et al. (1995) & $\mathrm{N} / \mathrm{A}$ & $\mathrm{N} / \mathrm{A}$ & Experimental Pilot Study & No & No \\
\hline Herzog et al. (1999) & $\mathrm{N} / \mathrm{A}$ & $\mathrm{N} / \mathrm{A}$ & Intervention Design & No & No \\
\hline Hu et al. (2014) & Yes & $\mathrm{N} / \mathrm{A}$ & RCT & Yes & Yes \\
\hline Hunter et al. (2006) & $\mathrm{N} / \mathrm{A}$ & Yes & Experimental Design & No & Yes \\
\hline Kamel et al. (2016) & Yes & Yes & RCT & Yes & Yes \\
\hline Ko et al. (2015) & Yes & Yes & RCT & Yes & No \\
\hline$\frac{\text { Krekoukias et al. }}{(2009)}$ & Yes & $\mathrm{N} / \mathrm{A}$ & RCT & Yes & Yes \\
\hline Langdon R. (2011) & Yes & $\mathrm{N} / \mathrm{A}$ & Clinical Crossover Study & No & No \\
\hline Niazi et al. (2015) & Yes & Yes & $\mathrm{RCT}$ & Yes & Yes \\
\hline$\frac{\text { Pecos-Martín et al. }}{(2017)}$ & Yes & Yes & $\mathrm{RCT}$ & Yes & No \\
\hline Reznik et al. (2015) & $\mathrm{N} / \mathrm{A}$ & $\mathrm{N} / \mathrm{A}$ & Preliminary Study & No & No \\
\hline Ribeiro et al. (2017) & Yes & Yes & $\begin{array}{l}\text { Cross-Over, Pre-Post Intervention } \\
\text { Study }\end{array}$ & No & No \\
\hline$\frac{\text { Ritvanen et al. }}{(2007)}$ & Yes & $\mathrm{N} / \mathrm{A}$ & $\begin{array}{c}\text { Prospective Clinical Trial, } 2 \\
\text { Intervention Groups }\end{array}$ & No & Yes \\
\hline Shih et al. (2018) & Yes & Yes & Cross-sectional RCT & Yes & Yes \\
\hline$\frac{\text { Shin. and Sung. }}{(2015)}$ & $\mathrm{N} / \mathrm{A}$ & $\mathrm{N} / \mathrm{A}$ & $\mathrm{RCT}$ & Yes & Yes \\
\hline Suter et al. (2005) & $\mathrm{N} / \mathrm{A}$ & $\mathrm{N} / \mathrm{A}$ & Intervention Study & No & No \\
\hline Xia et al. (2017) & Yes & N/A & Single-arm Clinical Trial & No & Yes \\
\hline Yoopat et al. (2015) & Yes & Yes & $\begin{array}{c}\text { Randomized Complete-Block Design } \\
\text { Experiment }\end{array}$ & No & Yes \\
\hline
\end{tabular}

RCT - Randomized Controlled Trial; N/A - Not Available

Again, the impact of SM was the objective of Xia et al., (2017) they found no association of the application of this technique with the flexion-relaxation phenomenon (FRP). Evidence that SM can reduce the transcranial magnetic stimulation (TMS) induced cortical silence and increased low-threshold motoneurone excitability in the Tibialis Anterior (TA) muscle was found by Haavik et al., (2018). For a different technique, the study of Krekoukiad et al. (2009) applied PA mobilization to L3 vertebra to perceive its effect on Lumbar erector spinae (ES) and, it showed a significant decrease in the SEMG activity for the asymptomatic population. Similar findings in the SEMG activity by Pecos-Martina et al. (2017) the same technique (PA mobilization) but for the thoracic ES, on T7 vertebra, even if no differences in pain relief was found compared to the placebo group. Three studies targeted the calf area, triceps sural for Behm et al. (2013) and Shin and Sung (2015) and most muscles moving the knee joint by Cruz-Montecinos et al. (2017). In all of them was used massage and in the latter also mobilization. It was found that massage therapy with static stretching reduces spinal reflex excitability ( $\mathrm{H} / \mathrm{M}$ ratio) which significantly affecting contractile properties (Behm et al., 2013) in contrast with other findings in which massage increased EMG activity suggesting it can be a beneficial tool after EIMD (Exercise-induced Muscle Damage) (Shin and Sung., 2015). For the 
population of females with osteoarthrosis (OA) of the knee, using massage and mobilization for that condition showed that these techniques could be useful tools in modifying the muscular activation pattern, favourably modifying co-contraction, beneficial in decreasing joint overload (Cruz-Montecinos et al., 2017). The following three studies also looked at the effect of MT, particularly massage on the lower limb, just two for the Quadriceps Femoris (QF), Langdon (2011) and Begovic et al. (2016) and one in both the anterior and posterior aspects of the tight, Hunter et al. (2006). Langdon (2011) was interested in understanding how different pressure application during a massage can influence muscular activity, and they found that the use of light and moderate pressure before deep pressure prevents increasing muscle activity levels. When the concern is force production and neuromuscular recruitment, it was found that muscular activity is reduced after the massage but not caused by neuromuscular recruitment (Hunter et al., 2006).

Table 3. Use of SEMG in Manual Therapy: Intervention

\begin{tabular}{|c|c|c|c|c|c|}
\hline Author(s) & Symptoms & MT Techniques Used & $\begin{array}{c}\text { Duration of MT } \\
\text { I ntervention }\end{array}$ & $\begin{array}{l}\text { Who applied } \\
\text { the MT }\end{array}$ & $\begin{array}{c}\text { Area of the body } \\
\text { treated }\end{array}$ \\
\hline Barbosa et al. (2014) & No & HVLAT & $\mathrm{N} / \mathrm{A}$ & Therapist & $\mathrm{SI}$ \\
\hline Begovic et al. (2016) & No & TFM & $15 \mathrm{~m}$ & PT & LL \\
\hline$\underline{B e h m}$ et al. (2013) & No & Massage MTJ & $\begin{array}{c}1 \mathrm{~m} \text { (intervention); 30s } \\
\text { (control) }\end{array}$ & $\begin{array}{l}\text { Massage } \\
\text { therapist }\end{array}$ & LL \\
\hline$\frac{\text { Bialoszewski et al. }}{(2014)}$ & Yes & CST and TPT & $30 m$ & PT & Spine \\
\hline$\frac{\text { Cruz-Montecinos et al. }}{(2016)}$ & Yes & $\begin{array}{c}\text { Grade II Maitland Mob and } \\
\text { Soft-tissue }\end{array}$ & $35-40 m$ & PT & LL \\
\hline$\frac{\text { Currie et al. (2016) }}{\underline{\text { (a) }}}$ & Mixed & HVLAT & $\mathrm{N} / \mathrm{A}$ & Chiropractor & $\begin{array}{l}\text { L3 Lsp and } \\
\text { SI }\end{array}$ \\
\hline$\frac{\text { Currie et al. (2016) }}{\text { (b) }}$ & No & HVLAT & $\mathrm{N} / \mathrm{A}$ & Chiropractor & L3 and Lsp \\
\hline DeVocht et al. (2005) & Yes & HVLAT & $5-10 m$ & Chiropractor & Spine \\
\hline Domingo et al. (2017) & No & Massage & $5 m$ & $\begin{array}{l}\text { Massage } \\
\text { therapist }\end{array}$ & Shoulder and Csp \\
\hline$\frac{\frac{\text { Galindez- }}{\text { Ibarbengoetxea et al. }}}{(2018)}$ & Yes & HVLAT, TMJ Mob & $\mathrm{N} / \mathrm{A}$ & PT & Csp and TMJ \\
\hline$\frac{\text { Gentilcore-Saulnier et }}{\text { al. } 2010}$ & Yes & Soft-tissue Mob, Stretching & $60-75 m$ & PT & Vagina \\
\hline Haavik et al. (2018) & No & HVLAT & $15 \mathrm{~m}$ & Chiropractor & Spine \\
\hline$\frac{\text { Hagovska et al. }}{\frac{(2014)}{}}$ & Yes & Soft-tissue Mob & $\mathrm{N} / \mathrm{A}$ & $\begin{array}{l}\text { McKenzie } \\
\text { Therapist }\end{array}$ & Lsp \\
\hline Herzog et al. (1995) & No & HVLAT & $3-5 s$ & Chiropractor & Tsp \\
\hline Herzog et al. (1999) & No & HVLAT & $200 \mathrm{~ms}$ & Chiropractor & Spine \\
\hline$\frac{\text { Hu et al. (2014) }}{\text { Hunter et al. (2006) }}$ & $\begin{array}{l}\text { Mixed } \\
\text { No } \\
\text { Yes }\end{array}$ & $\begin{array}{l}\text { Spinal Mob } \\
\text { Massage } \\
\text { central PA Mob }\end{array}$ & $\begin{array}{l}2-4 h \\
30 m \\
2 m\end{array}$ & $\begin{array}{c}\text { PT } \\
\text { PT } \\
\text { Therapist }\end{array}$ & $\begin{array}{l}\text { Spine } \\
\text { LL } \\
\text { L3 Lsp }\end{array}$ \\
\hline Ko et al. (2015) & Yes & $\begin{array}{l}\text { Stretching } \\
\text { by Massage }\end{array}$ & $\mathrm{N} / \mathrm{A}$ & Patient & TMJ \\
\hline$\frac{\text { Krekoukias et al. }}{(2009)}$ & No & central PA Mob & $2 m$ & Researcher & L3 Lsp \\
\hline $\begin{array}{l}\text { Langdon R. (2011) } \\
\text { Niazi et al. (2015) }\end{array}$ & $\begin{array}{l}\text { No } \\
\text { Yes }\end{array}$ & $\begin{array}{l}\text { Massage } \\
\text { HVLAT }\end{array}$ & $\begin{array}{c}45 \mathrm{~s} \\
200 \mathrm{~ms}\end{array}$ & $\begin{array}{l}\text { Therapist } \\
\text { Chiropractor }\end{array}$ & $\stackrel{\mathrm{LL}}{\text { Spine and SI }}$ \\
\hline$\frac{\text { Pecos-Martín et al. }}{(2017)}$ & Yes & grade III central PA Mob & $3 m$ & Researcher & T7 Tsp \\
\hline 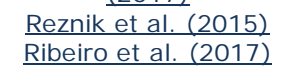 & $\begin{array}{l}\text { No } \\
\text { No }\end{array}$ & $\begin{array}{c}\text { PNF } \\
\text { Grade IV Mob }\end{array}$ & $\begin{array}{l}\mathrm{N} / \mathrm{A} \\
30 \mathrm{~s}\end{array}$ & $\begin{array}{l}\text { PT } \\
\text { PT }\end{array}$ & $\begin{array}{l}\mathrm{LL} \text { and UL } \\
\text { Shoulder }\end{array}$ \\
\hline Ritvanen et al. (2007) & Yes & $\begin{array}{l}\text { Bone setter Treatment and } \\
\text { Massage, Stretching }\end{array}$ & N/A & $\begin{array}{l}\text { Bone setter and } \\
\text { PT }\end{array}$ & All body treatment \\
\hline Shih et al. (2018) & Yes & Mob & $11 \mathrm{~m}$ & PT & Ankle \\
\hline$\frac{\text { Shin. and Sung. }}{(2015)}$ & Yes & Massage & $15 \mathrm{~m}$ & PT & LL \\
\hline$\frac{\text { Suter et al. (2005) }}{\text { Xia et al. (2017) }}$ & $\begin{array}{l}\text { Yes } \\
\text { Yes }\end{array}$ & $\begin{array}{l}\text { HVLAT } \\
\text { HVLAT }\end{array}$ & $\begin{array}{l}3 \mathrm{~s} \\
\mathrm{~N} / \mathrm{A}\end{array}$ & $\begin{array}{l}\text { Clinician } \\
\text { Chiropractor }\end{array}$ & $\begin{array}{l}\text { left SI joint } \\
\text { Lsp and SI J oint }\end{array}$ \\
\hline Yoopat et al. (2015) & No & Thai Massage & $15-30 m$ & $\begin{array}{l}\text { Massage } \\
\text { therapist }\end{array}$ & $\mathrm{N} / \mathrm{A}$ \\
\hline
\end{tabular}

For Begovic et al. (2016), the purpose was to understand the neuromotor changes associated with stiffness after applying transverse friction massage (TFM) over the QF's tendon in healthy subjects. His study shows that it decreases muscle stiffness but, there is an increased stiffness of the tendon caused by faster force transmission along with non-contractile elements. The four remaining studies focused on other anatomical areas. Barbosa et al. (2014) aimed to assess the immediate electrical changes on the transversus abdominis/internal oblique 
(TrA/IO) muscle during rapid voluntary upper limb movements before and after sacroiliac joint (SIJ) manipulation. An increase in electrical muscle activity was registered. The opposite result was found by Ribeiro et al. (2017) finding no differences in shoulder and scapular muscle activity levels in asymptomatic subjects, after an inferior shoulder mobilization. However, Domingo et al. (2017) found that short-duration moderate pressure massage on the trapezius muscle in asymptomatic participants significantly reduces electrical activity when comparing with quiet sitting. Finally, Gentilcore-Saulnier et al. (2010) aimed to determine the differences in pelvic floor muscle (PFM) behaviour, showing that woman with PVD have a higher tonic of EMG activity at rest. On a different note, Reznik et al. (2015) investigated the EMG pattern of overflow (changes in the contralateral limb), by manual resistive proprioceptive neuromuscular facilitation. They found that a resistance exercise would be effective at producing electrical activity in the contralateral homologous muscles of the non-exercised limb. Distinct work was designed by $\mathrm{Hu}$ et al. (2014) that found a significant difference in the root-mean-square (RMS) and root-mean-square difference (RMSD) analysis between healthy and symptomatic participants when doing a quantitative time-varying analysis of sEMG topography which may be a promising prognostic tool for rehabilitation of chronic LBP.

\subsection{Reported data}

Only three studies described all the chosen analysis parameters in terms of the demographic, methodologic and intervention data, as shown in Tables 1-3; these were Gentilcore-Saulnier et al. (2010), Cruz-Montecinos et al. (2016), and Pecos-Martina el al. (2017). Niazi et al. (2015) and Ribeiro et al. (2017) failed to report one parameter only. Six studies failed to publish five or more of those parameters, decreasing the information available to reproduce their study.

Although most elements are considered very important to assure reproducibility, in clinical trials, it is expected that the inclusion and exclusion criteria for the eligibility of participants are reported. According to Van Spall et al. (2007), exclusion criteria are not always stated in RCT's published in major medical journals.

Not having these available to the reader affects its reproducibility, potentially reducing the quality of the evidence. In our analysis, were found omission rates of $\sim 22 \%$ for the inclusion and exclusion criteria.

Other items, considered relevant by Bartuzi et al. (2010), were not always reported and could also condition the interpretation of the results as:

- The sex of the participants $(\sim 16 \%)$

- $\quad B M I$ of the participants $(\sim 38 \%)$

- Mean age of the participants ( 7\%)

Also, the omission of other variables as assessment by a Health Professional $(\sim 45 \%)$, duration of treatment $(\sim 29 \%)$ and area of the body treated ( $\sim 3 \%)$ may be considered relevant.

\subsection{Risk of Bias}

Table 4 shows that there is an overall low-quality, only four studies out of 31 scored 3 or more points in the Jadad scale, and only Pecos-Martina et al. (2017) got the full score for this quality scale.

The work of Jadad et al. (1996) is, according to Olivo et al. (2008), the most widely used in the world with over 3000 citations at the date of that publication, even if regarded as simplistic (Berger, 2006), it was considered an adequate means to evaluate the risk of bias of the selected studies. 
Table 4. Risk of bias in the clinical trial studies, using the Jadad scale.

\begin{tabular}{|c|c|c|c|c|c|c|}
\hline Author(s) & $\begin{array}{l}\text { Was the Study } \\
\text { Randomized? }\end{array}$ & $\begin{array}{l}\text { Was the Method of } \\
\text { Randomization Described } \\
\text { and Appropriate? }\end{array}$ & $\begin{array}{l}\text { Was the Study } \\
\text { Double-Blind? }\end{array}$ & $\begin{array}{c}\text { Was the Blinding Method } \\
\text { Described and } \\
\text { Appropriate? }\end{array}$ & $\begin{array}{c}\text { Was there a } \\
\text { Description } \\
\text { of } \\
\text { Withdrawals } \\
\text { and } \\
\text { Dropoffs? } \\
\end{array}$ & Total \\
\hline$\frac{\text { Barbosa et al. }}{(2014)}$ & 0 & 0 & 0 & 0 & 0 & 0 \\
\hline$\frac{\text { Begovic et al. }}{(2016)}$ & 1 & 1 & 0 & 0 & 1 & 3 \\
\hline$\frac{\text { Behm et al. }}{(2013)}$ & 1 & -1 & 0 & 0 & 0 & 0 \\
\hline$\frac{\text { Bialoszewski et }}{\frac{\text { al. }(2014)}{\text { Cruz- }}}$ & 1 & 1 & 0 & 0 & 0 & 2 \\
\hline$\frac{\text { Montecinos et }}{\text { al. (2016) }}$ & 1 & 1 & 0 & 0 & 0 & 2 \\
\hline$\frac{\text { Currie et al. }}{(2016)(a)}$ & 0 & 0 & 0 & 0 & 0 & 0 \\
\hline$\frac{\text { Currie et al. }}{(2016)(b)}$ & 0 & 0 & 0 & 0 & 0 & 0 \\
\hline$\frac{\text { DeVocht et al. }}{(2005)}$ & 0 & 0 & 0 & 0 & 0 & 0 \\
\hline$\frac{\text { Domingo et al. }}{\underline{\text { Galindez- }}}$ & 1 & -1 & 0 & 0 & 0 & 0 \\
\hline$\frac{\text { Ibarbengoetxea }}{\frac{\text { et al. (2018) }}{\text { Gentilcore- }}}$ & 1 & 1 & 0 & 0 & 1 & 3 \\
\hline$\frac{\text { saulnier et al. }}{\underline{2010}}$ & 0 & 0 & 0 & 0 & 0 & 0 \\
\hline$\frac{\text { Haavik et al. }}{(2018)}$ & 1 & -1 & 0 & 0 & 0 & 0 \\
\hline$\frac{\text { Hagovska et al. }}{(2014)}$ & 0 & 0 & 0 & 0 & 0 & 0 \\
\hline$\frac{\text { Herzog et al. }}{(1995)}$ & 0 & 0 & 0 & 0 & 0 & 0 \\
\hline$\frac{\text { Herzog et al. }}{(1999)}$ & 0 & 0 & 0 & 0 & 0 & 0 \\
\hline Hu et al. (2014) & 0 & 0 & 0 & 0 & 0 & 0 \\
\hline$\frac{\text { Hunter et al. }}{(2006)}$ & 0 & 0 & 0 & 0 & 0 & 0 \\
\hline$\frac{\text { Kamel et al. }}{(2016)}$ & 1 & -1 & 0 & 0 & 0 & 0 \\
\hline Ko et al. (2015) & 0 & 0 & 0 & 0 & 0 & 0 \\
\hline$\frac{\text { Krekoukias et }}{\text { al. (2009) }}$ & 1 & -1 & 0 & 0 & 0 & 0 \\
\hline$\frac{\text { Langdon R. }}{(2011)}$ & 1 & -1 & 0 & 0 & 1 & 1 \\
\hline$\frac{\text { Niazi et al. }}{(2015)}$ & 0 & 0 & 0 & 0 & 0 & 0 \\
\hline$\frac{\text { Pecos-Martín et }}{\text { al. (2017) }}$ & 1 & 1 & 1 & 1 & 1 & 5 \\
\hline$\frac{\text { Reznik et al. }}{(2015)}$ & 0 & 0 & 0 & 0 & 0 & 0 \\
\hline$\frac{\text { Ribeiro et al. }}{(2017)}$ & 0 & 0 & 0 & 0 & 0 & 0 \\
\hline$\frac{\text { Ritvanen et al. }}{(2007)}$ & 1 & 1 & 0 & 1 & 0 & 3 \\
\hline$\frac{\text { Shih et al. }}{\underline{(2018)}}$ & 1 & -1 & 0 & 0 & 1 & 1 \\
\hline$\frac{\text { Shin. and Sung. }}{(2015)}$ & 1 & -1 & 0 & 0 & 0 & 0 \\
\hline$\frac{\text { Suter et al. }}{(2005)}$ & 0 & 0 & 0 & 0 & 0 & 0 \\
\hline$\frac{\text { Xia et al. }}{(2017)}$ & 0 & 0 & 0 & 0 & 1 & 1 \\
\hline$\frac{\text { Yoopat et al. }}{(2015)}$ & 1 & -1 & 0 & 0 & 0 & 0 \\
\hline
\end{tabular}

\section{DI SCUSSION}

From the analysis of the results, above $70 \%$ of the authors were mostly concerned with detecting electric alterations in the muscle function. The reasons were to be able to develop stable protocols on how to retrieve the electrical signal as well as verifying causality between MT and electrical activity in muscles. The remaining papers had a more clinical purpose, $\sim 21 \%$ were interested in verifying the efficacy/effectiveness of the MT intervention in symptoms; sEMG seemed to help retrieve meaningful information about the electrical muscle activity and correlate with the changes in reported symptoms. The remaining category of aims compared 
treatment protocols, this accounted for $\sim 9 \%$ of all the articles purposes.

Clinically, although promising, it seems that there isn't yet a stable relationship between muscle activity and variation of the EMG signal. Therefore, it makes sense that most of the recent studies were designed to develop a better understanding of the SEMG protocols and procedures on how to collect the most usable information, so it can be used for clinical purposes.

In terms of the characterization of the methodology and design of the included studies, recruitment of participants was evenly distributed by a public call, university, hospital, and volunteer. Some of the studies selected had an uneven sex distribution which can affect results due to the differences in muscle physiology. SEMG was the only measurement technique used for $\sim 58 \%$ of the studies, in the studies that used other measurements or scales, the most used were VAS (Visual Analogue Scale), ODI (Oswestry Disability Index) and force measurement. Only half of the studies used control groups. The most used MT techniques were mobilization, massage, and HVLAT (Figure 1). $\sim 16 \%$ of all included works used more than one MT technique. Fourteen studies used asymptomatic participants and two a combination of symptomatic and asymptomatic.

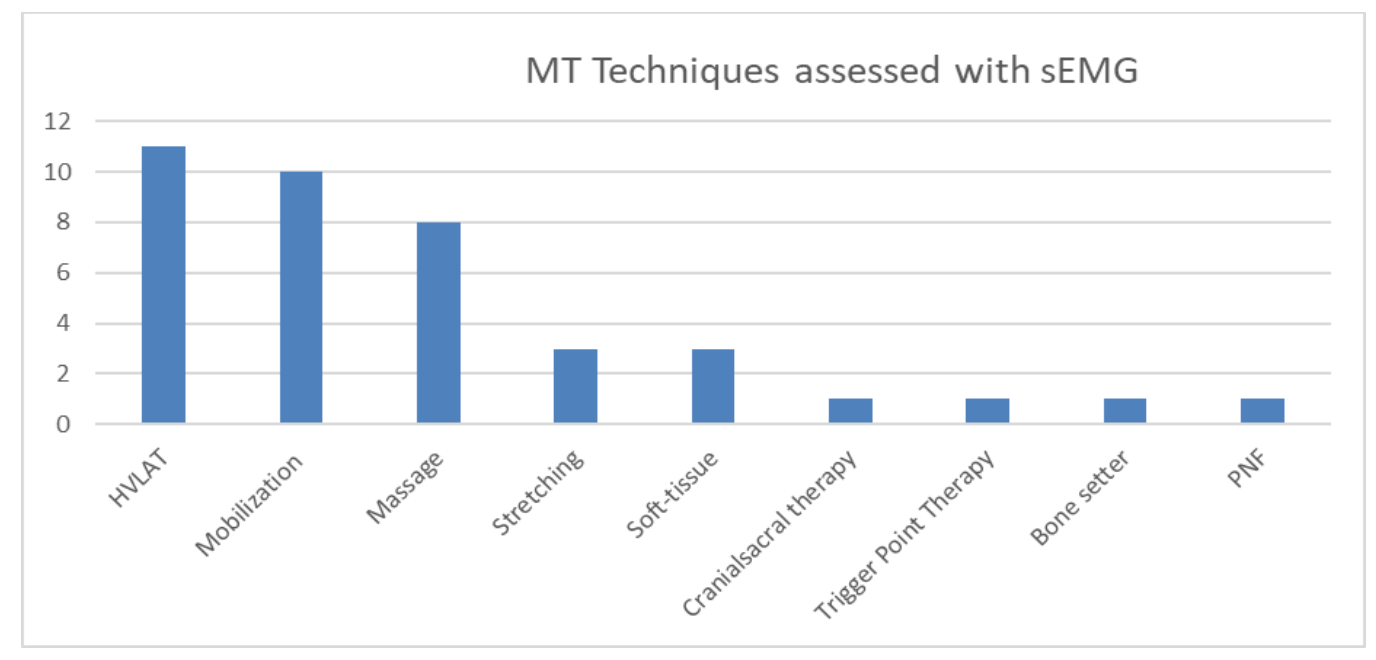

Figure 1. MT Techniques assessed with SEMG.

Regarding the professions represented in each study (Figure 2), physiotherapy was present in 12 articles, followed by Chiropractor with eight.

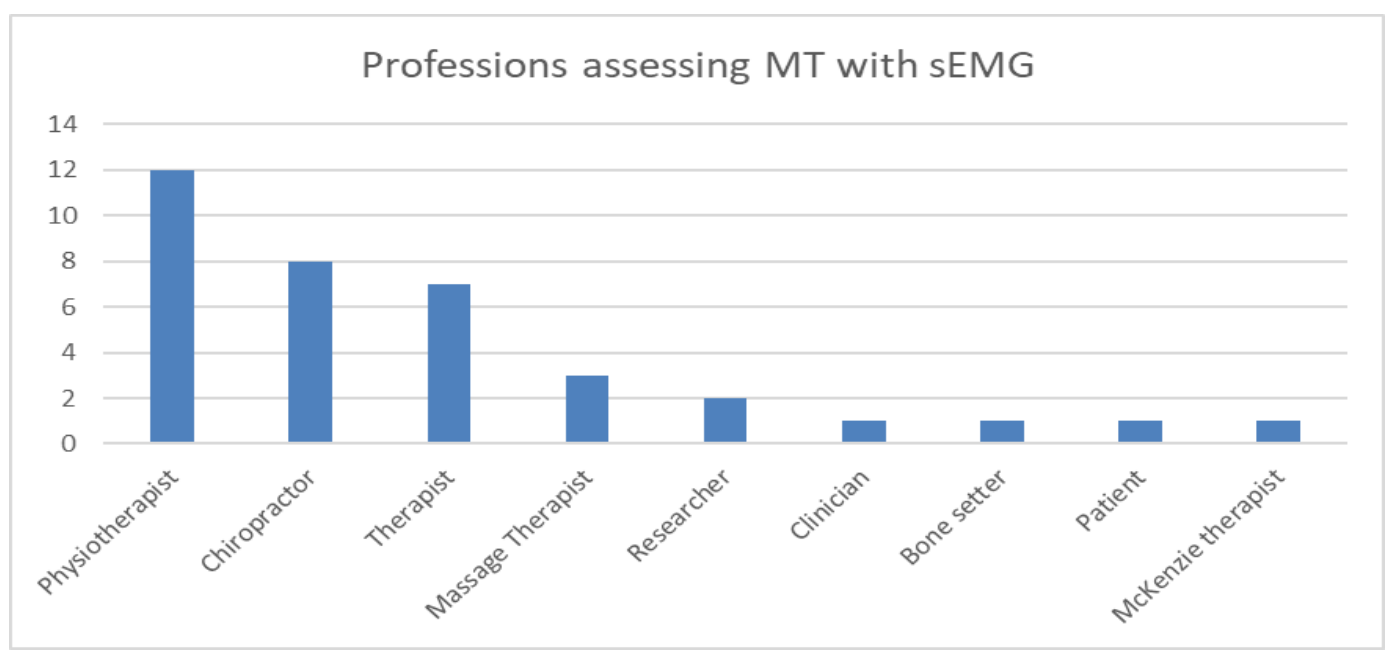

Figure 2. Which professions assessed MT using SEMG. 
The areas of the body most used by this selection of studies were lower-limb (LL), present in eight studies, followed by lumbar spine with six and spine with five presences. Interesting to note how this selection of studies included authors from all over the world, representing the five continents, being the most present, North America with ten studies and the most represented countries are USA and Canada. This characterization shows how heterogeneous the existing evidence is, in terms of design, in the study of MT using SEMG.

The information about EMG signal data acquisition and analysis are also essential for the study's reproducibility and quality, its criteria are described in Table 5. Details on how the EMG data was retrieved should be clearly described. Explicitly stating the choices regarding electrodes type and location, EMG detection, sampling, normalization, rectification, and amplitude process is essential. Without this information, the study cannot be replicated. Training for health professionals' authors on how to adequately acquire and report sEMG data should be considered.

The ISEK's standards for reporting EMG data describes these standards and states that this information should be supplied in the Methods section of the manuscripts using EMG (Standards for Reporting EMG Data, 2018). For this review, the ISEK's standards results were summarised in Table 5 and the compliance with reporting its items presented in Figure 3.

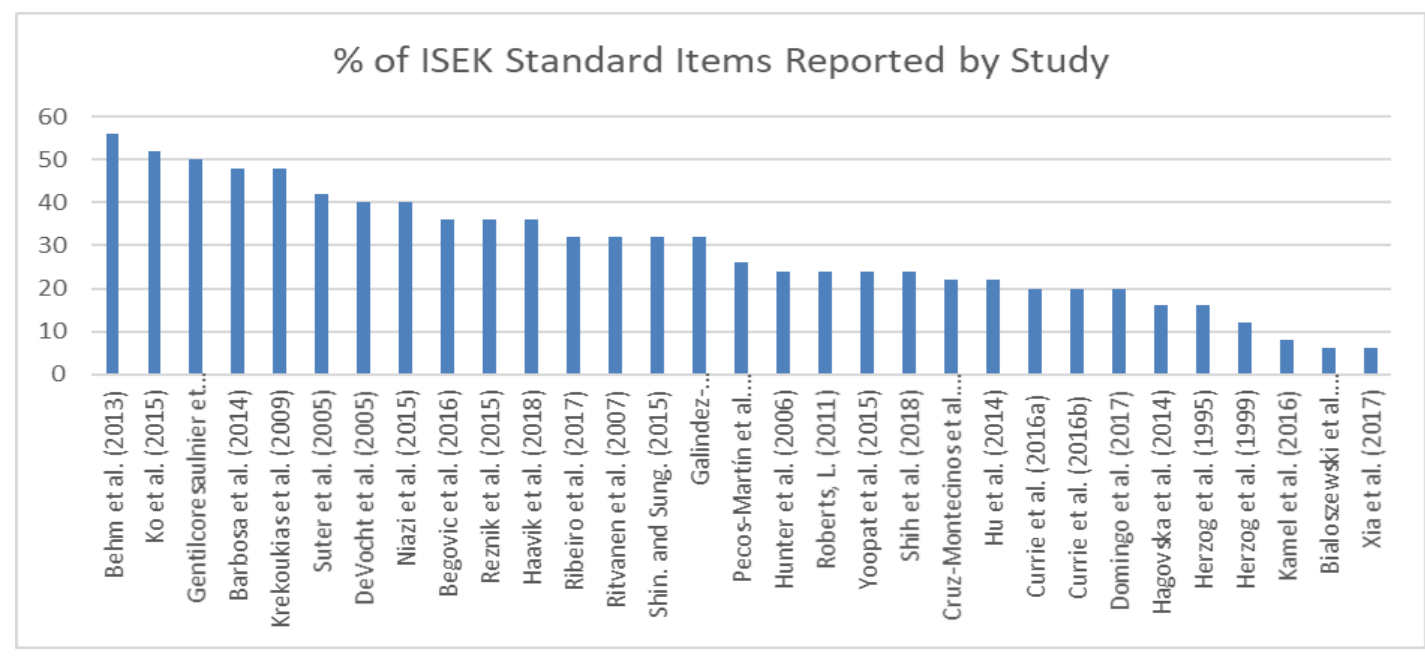

Figure 3. Percentage of ISEK standard criteria not reported by each study

When analyzing the percentage of the detailed elements, it was found that only three studies reached or passed $50 \%$ of the reported items. Close to half of the articles stated less than $25 \%$ of all elements, showing a general low potential to be replicated. When observing which items were mostly reported, we can observe that Location was by far the one that almost all studies reported, only Bialoszewski et al., (2014) and Xia et al., (2017) did not.

The most missing items were the Shape of the electrode, SNR, Slopes of the cut-off and most of the Normalisation items. For some studies, due to their specific design and objectives, wouldn't make sense to report some of those items and therefore it cannot be interpreted as a failure to report. For instance, the normalization items should only be reported when force/torque needs to be correlated to the EMG, when the maximum voluntary contraction ( $M V C)$, needs to be estimated. Another case is when the participant is required to perform an isometric contraction; then the joint angle is relevant, if one is looking at non-isometric contraction then ranges of joint angle, and velocity of shortening are important (Standards for Reporting EMG Data, 2018). Future evaluations of the quality of the reporting of sEMG should contemplate these procedures. 
Table 5. Check-list for the ISEK standards for reporting EMG data. Format adapted from Januario et al., (2016)

\begin{tabular}{|c|c|c|c|c|c|c|c|c|c|c|c|c|c|c|}
\hline \multirow[t]{2}{*}{ Study } & \multicolumn{6}{|l|}{$\begin{array}{c}\text { Surface } \\
\text { Electrode }\end{array}$} & \multicolumn{8}{|l|}{ EMG detection } \\
\hline & Material & Shape & Size & $\begin{array}{c}\text { Skin } \\
\text { Preparation }\end{array}$ & $\begin{array}{l}\text { Int. } \\
\text { electrode } \\
\text { distance }\end{array}$ & Location & $\begin{array}{c}\text { Type of } \\
\text { differential }\end{array}$ & $\begin{array}{c}\text { Input } \\
\text { Impedance }\end{array}$ & CMRR & SNR & Gain & $\begin{array}{l}\text { Filter } \\
\text { Types }\end{array}$ & $\begin{array}{l}\text { Cut-off } \\
\text { frequencies }\end{array}$ & $\begin{array}{l}\text { Slopes } \\
\text { of the } \\
\text { cut-off }\end{array}$ \\
\hline Barbosa et al. (2014) & + & - & + & + & + & + & - & + & + & + & - & + & + & - \\
\hline Begovic et al. (2016) & + & - & - & + & + & + & + & - & - & - & + & + & + & - \\
\hline Behm et al. (2013) & + & - & + & + & + & + & + & + & + & + & + & + & + & - \\
\hline Bialoszewski et al. (2014) & \pm & - & - & - & - & - & - & - & - & - & - & - & - & - \\
\hline Cruz-Montecinos et al. (2016) & - & - & - & \pm & - & + & - & - & - & - & - & + & + & - \\
\hline Currie et al. (2016a) & - & - & - & - & - & + & - & - & - & - & - & + & + & - \\
\hline Currie et al. (2016b) & - & - & - & - & - & + & - & - & - & - & - & + & + & - \\
\hline DeVocht et al. (2005) & + & + & + & + & - & + & + & - & - & - & - & + & + & - \\
\hline Domingo et al. (2017) & - & - & - & - & - & + & - & - & - & - & - & + & + & - \\
\hline $\begin{array}{c}\text { Galindez-I barbengoetxea et al. } \\
\text { (2018) }\end{array}$ & - & + & + & + & - & + & - & - & - & - & - & + & + & - \\
\hline Gentilcoresaulnier et al. (2010) & + & \pm & + & - & + & + & + & + & + & - & + & - & + & - \\
\hline Haavik et al. (2018) & + & - & + & + & + & + & - & + & - & - & - & + & + & - \\
\hline Hagovska et al. (2014) & - & - & - & + & + & + & - & - & - & - & - & - & + & - \\
\hline Herzog et al. (1995) & + & - & - & + & - & + & + & - & - & - & - & - & - & - \\
\hline Herzog et al. (1999) & - & - & - & + & + & + & - & - & - & - & - & - & - & - \\
\hline Hu et al. (2014) & - & - & + & + & - & + & - & - & - & - & - & - & + & - \\
\hline Hunter et al. (2006) & \pm & - & - & + & - & + & - & - & - & - & - & - & + & - \\
\hline Kamel et al. (2016) & - & - & - & + & - & + & - & - & - & - & - & - & - & - \\
\hline Ko et al. (2015) & + & - & - & + & \pm & + & - & + & + & - & + & - & + & - \\
\hline Krekoukias et al. (2009) & \pm & - & - & + & - & + & + & + & + & + & + & - & + & - \\
\hline Niazi et al. (2015) & + & - & + & - & + & + & + & - & - & - & - & + & + & - \\
\hline Pecos-Martín et al. (2017) & \pm & - & - & \pm & + & + & + & - & - & - & - & - & - & - \\
\hline Reznik et al. (2015) & + & - & - & - & + & + & - & + & - & - & - & - & + & - \\
\hline Ribeiro et al. (2017) & + & - & - & + & + & + & - & - & - & - & + & - & - & - \\
\hline Ritvanen et al. (2007) & + & - & - & + & - & + & + & - & - & - & - & - & + & - \\
\hline Roberts, L. (2011) & - & - & - & + & + & + & - & + & - & - & - & - & + & - \\
\hline Shih et al. (2018) & + & - & - & - & - & + & - & - & - & - & - & + & + & - \\
\hline Shin. and Sung. (2015) & + & - & - & + & - & + & - & - & - & - & - & + & + & - \\
\hline Suter et al. (2005) & + & - & + & + & + & + & - & - & - & - & + & + & + & - \\
\hline Xia et al. (2017) & \pm & - & - & - & - & - & - & - & - & - & - & - & - & - \\
\hline Yoopat et al. (2015) & - & - & - & - & - & + & - & - & - & - & - & - & - & - \\
\hline
\end{tabular}


Table 5. Check-list for the ISEK standards for reporting EMG data. Format adapted from Januario et al., (2016) (continued).

\begin{tabular}{|c|c|c|c|c|c|c|c|c|c|c|c|c|c|}
\hline \multirow[t]{2}{*}{ Study } & \multicolumn{2}{|l|}{ Sampling } & \multicolumn{7}{|l|}{ Normalization } & \multirow[t]{2}{*}{ Rectification } & \multirow{2}{*}{$\begin{array}{c}\text { Amplitude } \\
\text { Process }\end{array}$} & \multirow{2}{*}{$\begin{array}{c}\text { Summed } \\
+/-^{-}\end{array}$} & \multirow{2}{*}{$\begin{array}{c}\text { Total } \\
\text { Score } \\
(\%)\end{array}$} \\
\hline & Frequency & Bits & $\begin{array}{l}\text { Training of } \\
\text { contraction }\end{array}$ & $\begin{array}{l}\text { Joint } \\
\text { angle }\end{array}$ & Conditions & $\begin{array}{l}\text { Rate of } \\
\text { Rise }\end{array}$ & Velocity & Ranges & Load & & & & \\
\hline Barbosa et al. (2014) & + & + & - & - & - & - & - & - & - & - & - & $12+/ 13-$ & $12(48)$ \\
\hline Begovic et al. (2016) & + & - & - & - & - & - & - & - & - & - & - & $9+/ 16-$ & $9(36)$ \\
\hline Behm et al. (2013) & + & + & - & - & - & - & - & - & - & - & - & $14+/ 11-$ & $14(56)$ \\
\hline Bialoszewski et al. (2014) & - & - & - & - & - & - & - & - & - & - & - & $1+/ 24-$ & $1.5(6)$ \\
\hline Cruz-Montecinos et al. (2016) & - & - & + & - & - & - & - & - & - & - & + & $5+/ 20-$ & $5.5(22)$ \\
\hline Currie et al. (2016a) & + & - & - & - & - & - & - & - & - & + & - & $5+/ 20-$ & $5(20)$ \\
\hline Currie et al. (2016b) & + & - & - & - & - & - & - & - & - & + & - & $5+/ 20-$ & $5(20)$ \\
\hline DeVocht et al. (2005) & + & - & - & - & - & - & - & - & - & - & + & $10+/ 15$ & $10(40)$ \\
\hline Domingo et al. (2017) & + & - & - & - & - & - & - & - & - & + & - & $5+/ 20-$ & $5(20)$ \\
\hline $\begin{array}{l}\text { Galindez-I barbengoetxea et al. } \\
\text { (2018) }\end{array}$ & + & - & - & - & - & - & - & - & - & - & - & $7+/ 18$ & $8(32)$ \\
\hline Gentilcoresaulnier et al. (2010) & + & + & + & - & - & - & - & - & - & - & - & $12+/ 13-$ & $12.5(50)$ \\
\hline Haavik et al. (2018) & + & - & - & - & - & - & - & - & - & - & - & $9+/ 16-$ & $9(36)$ \\
\hline Hagovska et al. (2014) & - & - & - & - & - & - & - & - & - & - & - & $4+/ 21-$ & $4(16)$ \\
\hline Herzog et al. (1995) & - & - & - & - & - & - & - & - & - & - & \pm & $4+/ 21-$ & $4(16)$ \\
\hline Herzog et al. (1999) & - & - & - & - & - & - & - & - & - & - & \pm & $3+/ 22-$ & $3(9)$ \\
\hline Hu et al. (2014) & + & - & - & - & - & - & - & - & - & - & \pm & $5+/ 20-$ & $5.5(22)$ \\
\hline Hunter et al. (2006) & + & - & + & - & - & - & - & - & - & - & \pm & $5+/ 20-$ & $6(24)$ \\
\hline Kamel et al. (2016) & - & - & - & - & - & - & - & - & - & - & - & $2+/ 23-$ & $2(4)$ \\
\hline Ko et al. (2015) & + & + & + & + & + & - & - & - & - & - & \pm & $12+/ 13$ & $13(52)$ \\
\hline Krekoukias et al. (2009) & + & - & + & - & + & - & - & - & - & - & \pm & $11+/ 14-$ & $12(48)$ \\
\hline Niazi et al. (2015) & + & - & + & - & + & - & - & - & - & - & - & $10+/ 15-$ & $10(40)$ \\
\hline Pecos-Martín et al. (2017) & + & + & - & - & - & - & - & - & - & - & \pm & $5+/ 20$ & $6.5(26)$ \\
\hline Reznik et al. (2015) & + & - & + & - & + & - & - & - & - & - & + & $9+/ 16-$ & $9(36)$ \\
\hline Ribeiro et al. (2017) & + & - & + & - & + & - & - & - & - & - & - & $8+/ 17-$ & $8(32)$ \\
\hline Ritvanen et al. (2007) & - & - & \pm & - & + & - & - & - & - & + & \pm & $7+/ 18-$ & $8(32)$ \\
\hline Roberts, L. (2011) & + & - & - & - & - & - & - & - & - & - & - & $6+/ 19-$ & $6(24)$ \\
\hline Shih et al. (2018) & + & - & - & - & - & - & - & - & - & - & + & $6+/ 19-$ & $6(24)$ \\
\hline Shin. and Sung. (2015) & + & - & \pm & - & + & - & - & - & - & + & - & $8+/ 17$ & $8(32)$ \\
\hline Suter et al. (2005) & + & + & - & - & - & - & - & - & - & - & \pm & $10+/ 15-$ & $10.5(42)$ \\
\hline Xia et al. (2017) & - & - & - & - & - & - & - & - & - & - & - & $1+/ 24-$ & $1.5(6)$ \\
\hline Yoopat et al. (2015) & + & - & + & + & + & - & - & - & + & - & - & $6+/ 19-$ & $6(24)$ \\
\hline $\begin{array}{l}\text { Surface electrode: electrode ma } \\
\text { skin, skin abrasion, shaving of } \\
\text { differential); CMRR - Common } \\
\text { dB/decade). Normalization: Ran } \\
\text { point in the total score); - - infor }\end{array}$ & $\begin{array}{l}\text { and Load ( } \\
\text { on not des }\end{array}$ & lectr & $\begin{array}{l}\text { pe (discs, ba } \\
\text { tation over } n \\
\text { nal to noise } \\
\text { c contractiol } \\
\text { ts summed }\end{array}$ & $\begin{array}{l}\text { ld b } \\
\text { tota }\end{array}$ & $\begin{array}{l}\text {; size (d } \\
\text { ig tendor } \\
\text { es (Butteı } \\
\text { cribed). } \\
\text { e). }\end{array}$ & $\begin{array}{l}\text { ter, rad } \\
\text { otor po } \\
\text { ch, Chel } \\
\text { mplete }\end{array}$ & $\begin{array}{l}\text { width } \\
\text { nd fibr } \\
\text { ev); cu } \\
\text { mation }\end{array}$ & $\begin{array}{l}\text { gth); s } \\
\text { ection) } \\
\text { freque } \\
\text { mmed }\end{array}$ & $\begin{array}{l}\text { repa } \\
\text { G de } \\
\text { s (lov } \\
\text { int in }\end{array}$ & $\begin{array}{l}\text { (use of ge } \\
\text { on: type of } \\
\text { ss, high pas } \\
\text { total score) }\end{array}$ & $\begin{array}{l}\text { paste, alc } \\
\text { rential }(\mathrm{m} \\
\text { lopes of } \mathrm{t} \\
\text { partial in }\end{array}$ & $\begin{array}{l}\text { I applied } \\
\text { polar, do } \\
\text { cut-offs (c } \\
\text { nation (si }\end{array}$ & $\begin{array}{l}\text { cleanse } \\
\text { le } \\
\text { octave, } \\
\text { med } 0,5\end{array}$ \\
\hline
\end{tabular}


Few studies stated that all procedures were conducted according to the Surface Electromyography for the non-Invasive Assessment of Muscle (SENIAM) recommendations; these were Barbosa et al., (2014), Bialoszewski et al., (2014), Cruz-Montecinos et al., (2016), Reznik et al., (2015), Ribeiro et al., (2017) and Shih et al., (2017). Although, the authors support for good practice the reference to these standards, since it doesn't substitute reporting in the publication for easier access to that information and facilitate its reproducibility. A possible reason for researchers having failed to report the recommended parameters is the lack of appropriate training in using SEMG to study MT. University programs for health professions should consider including a modular subject on EMG and its acquisition and analysis techniques, so future researchers can be proficient in using and reporting the use of this technique. Recent publications may be of great help for non-engineers, as manual therapists, by promoting the best practices in detecting SEMG (Merletti and Muceli, 2019) and proposing a guide on decision-making when recording, analyzing and interpreting EMG data (Besomi et al., 2019).

Some easily accessible and updated information about sEMG and its standards can be found at "https://www.robertomerletti.it/en/emg/material/teaching/". Previous and adequate training in using SEMG is strongly advised to increase the strength and value of these works.

\subsection{Limitations}

Regarding the limitations of this review, the findings are based on 31 studies. Unpublished literature was not searched, and only research published in English was used, making it possible that some relevant studies published in other languages have been missed. The three categories of purposes created may not represent all the objectives of the authors. Additionally, the authors recognize that the substantial heterogeneity found within the methodology of the included studies created difficulties in the analysis, potentially affecting the overall risk of bias assessment. Also, there are doubts regarding the Jadad scale being the most appropriate method for bias assessment.

\section{CONCLUSION}

Based on the results of the analysis of these studies, the purposes for using SEMG for MT were analyzed and categorized. There is high variability among areas of interest, and it shows that the most present objective is to improve or test different SEMG protocols to better retrieve the quality and interpretation of the electrical data. A much smaller number of articles had a clinical purpose, therefore there is insufficient evidence. Still, and arguably, sEMG isn't yet an effective method for analyzing the effects of MT.

The studies quality assessment using the Jadad scale showed how weak the overall quality was with only three studies ranking three or more points. Another finding of this review was the distribution of items that failed to report SEMG information. The authors assert the absolute importance for future studies to be accurate in their description of all the procedures and, more specifically, in reporting the use of SEMG according to the ISEK standards.

Future research should further examine the characteristics of the electric activity in muscles as a variable to increase our understanding of how MT works at that level. Although sEMG may be a promising technique to study the effects of MT, more studies are needed to create and validate more EMG technics and protocols so more clinically driven research can be directed at investigating the role of MT in health care.

\section{Conflict of interest}

The authors declare that there is no conflict of interest.

\section{Authors Contributions}

Development of study design and conduct: RJS, JSB. Coordination of study conduct: RJS, JTC. Title-/ abstract screening: JSB, JTC. Full-text screening: JSB, JTC. Data extraction: RJS, JMSB. Critical appraisal: RJS, JSB, JTC. Data analysis and interpretation: RJS, JSB. Support in data analysis and interpretation: RJS, JSB. Draft of the manuscript: RJS. Support in the draft of the manuscript: RJS, JSB, JTC, AFSM. All authors read and approved the final manuscript. 


\section{REFERENCES}

AL-MULLA, M. R., SEPULVEDA, F. \& COLLEY, M. 2011. A review of non-invasive techniques to detect and predict localised muscle fatigue. Sensors (Basel), 11, 3545-94. https://doi.org/10.3390/s110403545

ANDRONIS, L., KINGHORN, P., QIAO, S., WHITEHURST, D. G., DURRELL, S. \& MCLEOD, H. 2017. CostEffectiveness of Non-Invasive and Non-Pharmacological Interventions for Low Back Pain: a Systematic Literature Review. Appl Health Econ Health Policy, 15, 173-201. https://doi.org/10.1007/s40258-016-02688

ARMIJO-OLIVO, S., PITANCE, L., SINGH, V., NETO, F., THIE, N. \& MICHELOTTI, A. 2016. Effectiveness of Manual Therapy and Therapeutic Exercise for Temporomandibular Disorders: Systematic Review and MetaAnalysis. Physical therapy, 96, 9-25. https://doi.org/ 10.2522/ptj.20140548

BARBERO R., RAINOLDI A, MERLETTI R. 2012. Atlas of muscle innervation zones: understanding surface EMG and its applications, Springer.

BARBOSA, A. W. C., SILVA, A. M., SILVA, A. F., MARTINS, F. L. M. \& ALMEIDA BARBOSA, M. C. S. 2014. Immediate improvements in activation amplitude levels of the deep abdominal muscle following a sacroiliac joint manipulation during rapid upper limb movement. Journal of Bodywork and Movement Therapies, 18, 626-632. https://doi.org/ 10.1016/j.jbmt.2014.05.012

BARTUZI, P., TOKARSKI, T. \& ROMAN-LIU, D. 2010. The effect of the fatty tissue on EMG signal in young women. Acta Bioeng Biomech, 12, 87-92.

BEGOVIC, H., ZHOU, G. Q., SCHUSTER, S. \& ZHENG, Y. P. 2016. The neuromotor effects of transverse friction massage. Manual Therapy, 26, 70-76. https://doi.org/ 10.1016/j. math.2016.07.007

BEHM, D. G., PEACH, A., MADDIGAN, M., ABOODARDA, S. J., DISANTO, M. C., BUTTON, D. C. \& MAFFIULETTI, N. A. 2013. Massage and stretching reduce spinal reflex excitability without affecting twitch contractile properties. J Electromyogr Kinesiol, 23, 1215-21. https://doi.org/ 10.1016/j.jelekin.2013.05.002

BERGER, V. W. 2006. Is the Jadad score the proper evaluation of trials? J Rheumatol, 33, 1710-1; author reply 1711-2.

BESOMI, M., HODGES, P. W., VAN DIEEN, J., CARSON, R. G., CLANCY, E. A., DISSELHORST-KLUG, C., HOLOBAR, A., HUG, F., KIERNAN, M. C., LOWERY, M., MCGILL, K., MERLETTI, R., PERREAULT, E., SOGAARD, K., TUCKER, K., BESIER, T., ENOKA, R., FALLA, D., FARINA, D., GANDEVIA, S., ROTHWELL, J. C., VICENZINO, B. \& WRIGLEY, T. 2019. Consensus for experimental design in electromyography (CEDE) project: Electrode selection matrix. J Electromyogr Kinesiol, 48, 128-144.

BIALOSZEWSKI, D., BEBELSKI, M., LEWANDOWSKA, M. \& SLUPIK, A. 2014. Utility of craniosacral therapy in treatment of patients with non-specific low back pain. Preliminary report. Ortop Traumatol Rehabil, 16, 60515. https://doi.org/ 10.5604/15093492.1135120

BRONFORT, G., HAAS, M., EVANS, R., LEININGER, B. \& TRIANO, J. 2010. Effectiveness of manual therapies: the UK evidence report. Chiropr Osteopat, 18, 3. https:// doi.org/ 10.1186/1746-1340-18-3

CHOU, R. A. H., L. H. 2009. CLINICAL GUIDELINE FOR THE EVALUATION AND MANAGEMENT OF LOW BACK PAIN Evidence Review. American Pain Society.

CRUZ-MONTECINOS, C., FLORES-CARTES, R., MONTT-RODRIGUEZ, A., POZO, E., BESOAIN-SALDANA, A. \& HORMENT-LARA, G. 2016. Changes in co-contraction during stair descent after manual therapy protocol in knee osteoarthritis: A pilot, single-blind, randomized study. J Bodyw Mov Ther, 20, 740-747. https://doi.org/ 10.1016/j.jbmt.2016.04.017

CURRIE, S. J., MYERS, C. A., DURSO, C., ENEBO, B. A. \& DAVIDSON, B. S. 2016. The Neuromuscular Response to Spinal Manipulation in the Presence of Pain. Journal of Manipulative and Physiological Therapeutics, 39, 288-293. https://doi.org/10.1016/j.jmpt.2016.02.011

CURRIE, S. J., MYERS, C. A., KRISHNAMURTHY, A., ENEBO, B. A. \& DAVIDSON, B. S. 2016. Methods of Muscle Activation Onset Timing Recorded during Spinal Manipulation. Journal of Manipulative and Physiological Therapeutics, 39, 279-287. https://doi.org/10.1016/j.jmpt.2016.03.001

DEVOCHT, J. W., PICKAR, J. G. \& WILDER, D. G. 2005. Spinal manipulation alters electromyographic activity of paraspinal muscles: a descriptive study. J Manipulative Physiol Ther, 28, 465-71. https://doi.org/10.1016/j.jmpt.2005.07.002

DOMINGO, A. R., DIEK, M., GOBLE, K. M., MALUF, K. S., GOBLE, D. J. \& BAWEJ A, H. S. 2017. Short-duration therapeutic massage reduces postural upper trapezius muscle activity. Neuroreport, 28, 108-110. https: //doi.org/10.1097/wnr.0000000000000718

DROST, G., STEGEMAN, D. F., VAN ENGELEN, B. G. \& ZWARTS, M. J. 2006. Clinical applications of high-density surface EMG: a systematic review. J Electromyogr Kinesiol, 16, $586-602$. https://doi.org/10.1016/j.jelekin.2006.09.005 
ESPÍ-LÓPEZ, G. V., ARNAL-GÓMEZ, A., BALASCH-BERNAT, M. \& INGLÉS, M. 2017. Effectiveness of Manual Therapy Combined With Physical Therapy in Treatment of Patellofemoral Pain Syndrome: Systematic Review. Journal of Chiropractic Medicine, 16, 139-146. https://doi.org/10.1016/j.jcm.2016.10.003

FERNANDEZ-DE-LAS-PENAS, C., CLELAND, J., PALACIOS-CENA, M., FUENSALIDA-NOVO, S., PAREJA, J. A. \& ALONSO-BLANCO, C. 2017. The Effectiveness of Manual Therapy Versus Surgery on Self-reported Function, Cervical Range of Motion, and Pinch Grip Force in Carpal Tunnel Syndrome: A Randomized Clinical Trial. J Orthop Sports Phys Ther, 47, 151-161. https: //doi.org/10.2519/jospt.2017.7090

GALINDEZ-IBARBENGOETXEA, X., SETUAIN, I., RAMIREZ-VELEZ, R., ANDERSEN, L. L., GONZALEZ-IZAL, M., JAUREGI, A. \& IZQUIERDO, M. 2018. Short-term effects of manipulative treatment versus a therapeutic home exercise protocol for chronic cervical pain: A randomized clinical trial. J Back Musculoskelet Rehabil, 31, 133-145. https://doi.org/10.3233/BMR-169723

GENTILCORE-SAULNIER, E., MCLEAN, L., GOLDFINGER, C., PUKALL, C. F. \& CHAMBERLAIN, S. 2010. Pelvic floor muscle assessment outcomes in women with and without provoked vestibulodynia and the impact of a physical therapy program. J Sex Med, 7, 1003-22. https://doi.org/10.1111/j.1743-6109.2009.01642.x

GROENEWEG, R., VAN ASSEN, L., KROPMAN, H., LEOPOLD, H., MULDER, J., SMITS-ENGELSMAN, B. C. M., OSTELO, R., OOSTENDORP, R. A. B. \& VAN TULDER, M. W. 2017. Manual therapy compared with physical therapy in patients with non-specific neck pain: a randomized controlled trial. Chiropr Man Therap, $25,12$. https: // doi.org/10.1186/s12998-017-0141-3

GUDAVALLI, M. R., VINING, R. D., SALSBURY, S. A., CORBER, L. G., LONG, C. R., PATWARDHAN, A. G. \& GOERTZ, C. M. 2015. Clinician proficiency in delivering manual treatment for neck pain within specified force ranges. Spine J, 15, 570-6. https://doi.org/10.1016/j.spinee.2014.10.016

HAAVIK, H., NIAZI, I. K., J OCHUMSEN, M., UGINCIUS, P., SEBIK, O., YILMAZ, G., NAVID, M. S., OZYURT, M. G. \& TURKER, K. S. 2018. Chiropractic spinal manipulation alters TMS induced I-wave excitability and shortens the cortical silent period. J Electromyogr Kinesiol, 42, 24-35. https: // doi.org/10.1016/j.jelekin.2018.06.010

HAGOVSKA, M., TAKAČ, P. \& PETROVIČOVÁ, J. 2014. Changes in the muscle tension of erector spinae after the application of the McKenzie method in patients with chronic low back pain. Physikalische Medizin Rehabilitationsmedizin Kurortmedizin, 24, 133-140. https://doi.org/10.1055/s-0034- 1375671

HERZOG, W., CONWAY, P. J., ZHANG, Y. T., GAL, J. \& GUIMARAES, A. C. 1995. Reflex responses associated with manipulative treatments on the thoracic spine: a pilot study. J Manipulative Physiol Ther, 18, $233-6$.

HERZOG, W., SCHEELE, D. \& CONWAY, P. J. 1999. Electromyographic responses of back and limb muscles associated with spinal manipulative therapy. Spine (Phila Pa 1976), 24, 146-52; discussion 153. https: // doi.org/10.1097/00007632-199901150-00012

HU, Y., KWOK, J. W., TSE, J. Y. \& LUK, K. D. 2014. Time-varying surface electromyography topography as a prognostic tool for chronic low back pain rehabilitation. Spine J, 14, 1049-56. https: // doi.org/10.1016/j.spinee.2013.11.060

HUNTER, A. M., WATT, J. M., WATT, V. \& GALLOWAY, S. D. R. 2006. Effect of lower limb massage on electromyography and force production of the knee extensors. $\mathrm{Br} J$ Sports Med, 40, 114-8. https: // doi.org/ 10.1136/bjsm.2005.019075

JADAD, A. R., MOORE, R. A., CARROLL, D., JENKINSON, C., REYNOLDS, D. J., GAVAGHAN, D. J. \& MCQUAY, H. J. 1996. Assessing the quality of reports of randomized clinical trials: is blinding necessary? Control Clin Trials, 17, 1-12. https://doi.org/10.1016/0197-2456(95)00134-4

JANUARIO, L. B., MOREIRA RDE, F., CID, M. M., SAMANI, A., MADELEINE, P. \& OLIVEIRA, A. B. 2016. Effects of active pause pattern of surface electromyographic activity among subjects performing monotonous tasks: $A$ systematic review. J Electromyogr Kinesiol, 30, 196-208. https://doi.org/10.1016/j.jelekin.2016.07.009

KAMEL, D. M., RAOOF, N. A. A. \& TANTAWY, S. A. 2016. Efficacy of lumbar mobilization on postpartum low back pain in Egyptian females: A randomized control trial. Journal of Back and Musculoskeletal Rehabilitation, 29, 55-63. https: //doi. org/ 10.3233/BMR-150598

KO, E. W. C., TENG, T. T. Y., HUANG, C. S. \& CHEN, Y. R. 2015. The effect of early physiotherapy on the recovery of mandibular function after orthognathic surgery for class III correction. Part II: Electromyographic activity of masticatory muscles. Journal of Cranio-Maxillofacial Surgery, 43, $138-143$. https://doi.org/10.1016/j.jcms.2014.10.028

KREKOUKIAS, G., PETTY, N. J. \& CHEEK, L. 2009. Comparison of surface electromyographic activity of erector spinae before and after the application of central posteroanterior mobilisation on the lumbar spine. J Electromyogr Kinesiol, 19, 39-45. https://doi.org/10.1016/j.jelekin.2007.06.020

LEHMAN, G. 2012. Kinesiological research: the use of surface electromyography for assessing the effects of spinal manipulation. J Electromyogr Kinesiol, 22, 692-6. https://doi.org/10.1016/j.jelekin.2012.02.010

LIBERATI, A., ALTMAN, D. G., TETZLAFF, J., MULROW, C., GOTZSCHE, P. C., IOANNIDIS, J. P., CLARKE, M., DEVEREAUX, P. J., KLEIJ NEN, J. \& MOHER, D. 2009. The PRISMA statement for reporting systematic reviews 
and meta-analyses of studies that evaluate health care interventions: explanation and elaboration. PLoS Med, 6, e1000100. https://doi.org/10.1371/journal.pmed.1000100

LICCIARDONE, J. C. 2014. Short-term dosing of manual therapies for chronic low back pain. Spine J, 14, 10856. https://doi.org/10.1016/j.spinee.2013.12.015

MERLETTI, R., FARINA, D. (edts) 2016. Surface Electromyography: physiology, engineering and applications, IEEE Press / J Wiley, USA.

MERLETTI, R. 2018. Standards for Reporting EMG Data. Journal of Electromyography and Kinesiology, 42, I-II. https://doi.org/10.1016/S1050-6411(18)30348-1

MERLETTI, R., HOLOBAR, A. \& FARINA, D. 2008. Analysis of motor units with high-density surface electromyography. J Electromyogr Kinesiol, 18, 879-90. https://doi.org/10.1016/j.jelekin.2008.09.002

MERLETTI, R. \& MUCELI, S. 2019. Tutorial. Surface EMG detection in space and time: Best practices. J Electromyogr Kinesiol, 49, 102363.

MOHER, D., SHAMSEER, L., CLARKE, M., GHERSI, D., LIBERATI, A., PETTICREW, M., SHEKELLE, P., STEWART, L. A. \& GROUP, P.-P. 2015. Preferred reporting items for systematic review and meta-analysis protocols (PRISMA-P) 2015 statement. Syst Rev, 4, 1. https://doi.org/10.1186/2046-4053-4-1

MOORE, C. S., SIBBRITT, D. W. \& ADAMS, J. 2017. A critical review of manual therapy use for headache disorders: prevalence, profiles, motivations, communication and self-reported effectiveness. BMC Neurol, 17, 61. https://doi.org/10.1186/s12883-017-0835-0.

NIAZI, I. K., TURKER, K. S., FLAVEL, S., KINGET, M., DUEHR, J. \& HAAVIK, H. 2015. Changes in H-reflex and Vwaves following spinal manipulation. Exp Brain Res, 233, 1165-73. https://doi.org/10.1007/s00221-0144193-5

OLIVO, S. A., MACEDO, L. G., GADOTTI, I. C., FUENTES, J., STANTON, T. \& MAGEE, D. J. 2008. Scales to assess the quality of randomized controlled trials: a systematic review. Phys Ther, 88, 156-75. https: // doi.org/ 10.2522/ptj. 20070147

PARIS, S. V. 2000. History of Manipulative Therapy Through the Ages and Up to the Current Controversy in the United States. The Journal of Manual \& Manipulative Therapy, 8, 11. https: //doi.org/ 10.1179/106698100790819555

PECOS-MARTINA, D., AROEIRA, A. E. D., SILVA, R. L., POZO, G. M. D., SOLANO, L. M. R., PLAZA-MANZANO, G., GALLEGO-IZQUIERDO, T. \& FALLA, D. 2017. Immediate effects of thoracic spinal mobilisation on erector spinae muscle activity and pain in patients with thoracic spine pain: a preliminary randomised controlled trial. Physiotherapy, 103, 90-97. https://doi.org/10.1016/j.physio.2015.10.016

REID, S. A., RIVETT, D. A., KATEKAR, M. A. \& CALLISTER, R. 2014. Comparison of Mulligan Sustained Natural Apophyseal Glides and Maitland Mobilizations for Treatment of Cervicogenic Dizziness: A Randomized Controlled Trial. Physical Therapy, 94, 466-476. https://doi.org/10.2522/ptj.20120483

REZNIK, J. E., BIROS, E. \& BARTUR, G. 2015. An electromyographic investigation of the pattern of overflow facilitated by manual resistive proprioceptive neuromuscular facilitation in young healthy individuals: a preliminary study. Physiotherapy Theory and Practice, 31, 582-586. https://doi.org/10.3109/09593985.2015.1061627

RIBEIRO, D. C., DAY, A. \& DICKERSON, C. R. 2017. Grade-IV inferior glenohumeral mobilization does not immediately alter shoulder and scapular muscle activity: a repeated-measures study in asymptomatic individuals. Journal of Manual and Manipulative https: // doi.org/10.1080/10669817.2017.1290310

RITVANEN, T., ZAPROUDINA, N., NISSEN, M., LEINONEN, V. \& HANNINEN, O. 2007. Dynamic surface electromyographic responses in chronic low back pain treated by traditional bone setting and conventional physical therapy. J Manipulative Physiol Ther, 30, 31-7. https://doi.org/10.1016/j.jmpt.2006.11.010

ROBERTS, L. 2011. Effects of Patterns of Pressure Application on Resting Electromyography During Massage. Int J Ther Massage Bodywork, 4, 4-11. https://doi.org/10.3822/ijtmb.v4i1.25

SANTIAGO, R., SANTOS BAPTISTA, J. \& TORRES COSTA, J. 2018. Surface electromyography in manual therapy - categorization of purpose and quality of reporting: a systematic review protocol. International Journal of Occupational and Environmental Safety, 2, 64-74. https://doi.org/10.24840/2184-0954_002.002_0007

SHIH, Y. F., YU, H. T., CHEN, W. Y., LIAO, K. K., LIN, H. C. \& YANG, Y. R. 2018. The effect of additional joint mobilization on neuromuscular performance in individuals with functional ankle instability. Phys Ther Sport, 30, 22-28. https://doi.org/10.1016/j.ptsp.2017.12.001

SHIN, M. S. \& SUNG, Y. H. 2015. Effects of Massage on Muscular Strength and Proprioception after ExerciseInduced Muscle Damage. Journal of Strength and Conditioning Research, 29, 2255-2260. https://doi.org/10.1519/J SC. 0000000000000688 
SIMSON, K. J., MILLER, C. T., FORD, J., HAHNE, A., MAIN, L., RANTALAINEN, T., TEO, W. P., TEYCHENNE, M., CONNELL, D., TRUDEL, G., ZHENG, G., THICKBROOM, G. \& BELAVY, D. L. 2017. Optimising conservative management of chronic low back pain: study protocol for a randomised controlled trial. Trials, $18,184$. https://doi.org/10.1186/s13063-017-1913-8

SMITH, A. R., JR. 2007. Manual therapy: the historical, current, and future role in the treatment of pain. ScientificWorldJ ournal, 7, 109-20. https://doi.org/10.1100/tsw.2007.14

SUTER, E., MCMORLAND, G. \& HERZOG, W. 2005. Short-term effects of spinal manipulation on H-reflex amplitude in healthy and symptomatic subjects. J Manipulative Physiol Ther, 28, 667-72. https://doi.org/10.1016/j.jmpt.2005.09.017

SWAIT, G. \& FINCH, R. 2017. What are the risks of manual treatment of the spine? A scoping review for clinicians. Chiropr Man Therap, 25, 37. https://doi.org/10.1186/s12998-017-0168-5

VAN SPALL, H. G., TOREN, A., KISS, A. \& FOWLER, R. A. 2007. Eligibility criteria of randomized controlled trials published in high-impact general medical journals: a systematic sampling review. Jama, 297, 1233-40. https://doi.org/10.1001/jama.297.11.1233

WITHINGTON, E. 1944. Hippokrates, with an English translation. London: Heinemann, Vol III, $279-307$.

WONG, J. J., SHEARER, H. M., MIOR, S., JACOBS, C., COTE, P., RANDHAWA, K., YU, H., SOUTHERST, D., VARATHARAJAN, S., SUTTON, D., VAN DER VELDE, G., CARROLL, L. J., AMEIS, A., AMMENDOLIA, C., BRISON, R., NORDIN, M., STUPAR, M. \& TAYLOR-VAISEY, A. 2016. Are manual therapies, passive physical modalities, or acupuncture effective for the management of patients with whiplash-associated disorders or neck pain and associated disorders? An update of the Bone and Joint Decade Task Force on Neck Pain and Its Associated Disorders by the OPTIMa collaboration. Spine J, 16, 1598-1630. https: //doi.org/10.1016/j.spinee.2015.08.024

XIA, T., LONG, C. R., VINING, R. D., GUDAVALLI, M. R., DEVOCHT, J. W., KAWCHUK, G. N., WILDER, D. G. \& GOERTZ, C. M. 2017. Association of lumbar spine stiffness and flexion-relaxation phenomenon with patientreported outcomes in adults with chronic low back pain - a single-arm clinical trial investigating the effects of thrust spinal manipulation. BMC Complement Altern Med, 17, 303. https://doi.org/10.1186/s12906-0171821-1

YOOPAT, P., MAES, C., PORIAU, S. \& VANWONTERGHEM, K. 2015. Thai traditional massage: efficiencyassessment of three traditional massage methods on office workers: an explorative study. J Bodyw Mov Ther, 19, 246-52. https://doi.org/10.1016/j.jbmt.2014.04.006

YOUNG, I. A., MICHENER, L. A., CLELAND, J. A., AGUIleRA, A. J. \& SNYDER, A. R. 2009. Manual Therapy, Exercise, and Traction for Patients With Cervical Radiculopathy: A Randomized Clinical Trial. Physical Therapy, 89, 632-642. https://doi.org/10.2522/ptj.20080283 


\section{Appendix 1}

\section{SCOPUS}

( TITLE-ABS-KEY ( ( surface AND electromyography) AND ( ( manual AND therap* ) OR ( manual AND treatment) OR (occupational AND therap*) OR physiotherap* OR osteopath* OR chiro* OR orthop* OR massag*) AND NOT ( systematic AND review )) ) OR massag*)) AND NOT ( systematic AND review ))

\section{ScienceDirect}

(TITLE-ABS-KEY ( ( ( surface AND electromyography ) ) AND ( ( manual AND therap* ) OR (occupational AND therap*) OR physiotherap* OR osteopath* OR chiro* OR orthop* OR massag*) AND NOT (systematic AND review))

\section{WebOfScience}

(((( surface AND electromyography ) AND ( ( manual AND therap* ) OR (occupational AND therap*) OR physiotherap* OR osteopath* OR chiro* OR orthop* OR

massag* )) NOT (systematic AND review)))

\section{PUBMED}

1. ("surface electromyography"[All Fields]) AND ("manual therapist"[All Fields] OR ("occupational"[All Fields] AND "therapist"[All Fields]) OR "physiotherapist"[All Fields] OR

"osteopathic"[All Fields] OR "chiropractor"[All Fields] OR "orthopaedics"[All Fields] OR "massagist"[All Fields]) NOT "systematic review"[All Fields]

2. ("surface electromyography"[All Fields]) AND ("manual therapy"[All Fields] OR ("occupational"[All Fields] AND "therapy"[All Fields]) OR "physiotherapy"[All Fields] OR "osteopathy"[All Fields]

OR "chiropractic"[All Fields] OR "orthopedics"[All Fields] OR "massage"[All Fields]) NOT "systematic review"[All Fields]

\section{PEDRO}

surface AND electromyography and therapy

\section{Biomed CENTRAL} review)

( surface AND electromyography ) AND ( manual AND therapy ) NOT (systematic AND

\section{DOAJ}

( surface AND electromyography ) AND ( manual AND therap*)

\section{MEDLI NE OVI D} review))

((surface and electromyography and (manual and therapy)) not (systematic and 